\title{
ANIMAL METAPHORS IN “ $A$ WALK TO REMEMBER” NOVEL BY NICHOLAS SPARKS
}

\author{
Gracia M. N. Otta ${ }^{1}$ and Yuliana Nenohalan ${ }^{2}$ \\ Universitas Nusa Cendana \\ graciaotta@gmail.com
}

\begin{abstract}
Imagination of the author was very broad, that affects the impressions and imagination, where the readers were forced to have a free imagination in finding out the meanings and differences of each literary sentences. Using figurative language makes the novel more interesting also challenging to read, and the reades are pleased to imagine about the story based on the illustration. This article was conducted to identify and to describe the animal metaphors in literary sentences that contained in A Walk To Remember novel and to describe the meaning dennotatively and connotatively of each literary sentences. Descriptive qualitative method was applied since the data presented in the form of language. The data were collected through reading and identifying the metaphors found in the novel. The results of this study showed eight items of animal metaphors.
\end{abstract}

Keywords: A Walk To Remember, Connotative, Dennotative, Animal Metaphors, Novel

\section{Abstraksi}

Imajinasi penulis yang sangat luas membuat pembaca berimajinasi sebebas-bebasnya untuk menemukan makna dan perbedaan pada setiap kalimat sastra. Penggunaan bahasa kiasan membuat sebuah novel menjadi begitu menarik sekaligus menantang untuk dibaca. Artikel ini disusun untuk mengidentifikasi dan mendeskripsikan metafora kehewanan pada kalimatkalimat dalam novel $A$ Walk to Remember. Makna dianalisis secara denotatif dan konotatif dengan metode deskriptif kualitatif. Hasil penelitian menunjukkan bahwa, terdapat delapan item metafora kehewanan yang terdapat dalam novel tersebut.

\section{Kata kunci : A Walk to Remember, Konotatif, Denotatif, Metafora Kehewanan, Novel}

\section{INTRODUCTION}

In form of individuals and groups, language becomes an inseparable part of social life, religion, politics, culture, and also education. Regarding education, especially for students in language program, language becomes an important thing. Language as the foundation of everything they learned, for both native and foreign language, definitely with different aspects of each study. The study of language through a scientific study we called linguistics. As an object of language study, linguistics has several branches of study, there are phonetics, phonology, morphology, pragmatics and semantics.

Language cannot be separated from literature. The interpretation of literature was very broad, it depends on each individual. For the writers, literature is a beauty value which produced by someone's imagination that may not be understood by others, as other people also have different standards of beauty to literature. One way of written presentation which is 
considered have quite a lot of enjoyer is in the field of prose, where novel also one of the main study.

Commonly, discourse analysis that we found in novel is meaning analysis, regardless what concepts have been analyzed. This article discusses linguistics research related to semantics. Semantics is a branch of linguistic that study about the meaning of words contained in some language, code, or other type of representation. The meaning can be conveyed denotatively in accordance with the objective situation, and connotative, that is the meaning which comes from the social conditions around us. One of form that conveying connotative verbal meaning is the use of figurative language. The use of figurative language was easy to found in any kind of fictional literature.

In a broad sense, novel is a literary work that often use figurative language. Novel is an effect of the author's expression who gives some imaginative impressions for the audience with their each portions, which aims to provide its own effects for the readers. Figure of speech have a particular distinction to make a literary work more alive, in this case related to the imagination and feelings. (Risdianto, 2011) stated, that figurative language is wording that makes explicit comparisons between unlike things using figure of speech such as metaphors and similes. There are four types of figurative language; (1) figure of comparison, (2) figure of contradiction, (3) figure of correlation, and (4) figure of repetition (Tarigan, 1985). Figure of comparison is functioned to compare an object with other objects by equalizing, exaggerating or replacing.

Metaphor is one of the common figurative language in everyday life, both in oral and written. A metaphor is a figurative language like a comparison but does not uses the comparison word. Subjectively, A Walk to Remember Novel by Nicholas Sparks was used as data source. It is a romantic novel about teenage love story, where death separates their love. This was experienced by Landon Carter, who was considered as bad guy in society then turned to be a good guy since having relationship with a priest's daughter, Jamie Sullivan, where she later passed away because of cancer. The story attracted the attention of the readers with a romantic story, even when someone read with heart and feeling, might pick up the profound religious meaning, also the sentences used by the author in contained literary elements, related to the use of figurative language. Another fact, this novel is also one of best seller novels that written by Nicholas Sparks.

\section{RELATED LITERATURE}

In most cases, literature is reffered to as the entirety of written expression, with the restriction that not every written document can be categorized as literature in the more exact sense of the word (Klarer, 2013). Literature can be divided into written literature and oral literature. In this case, literature is more related with language used as a mode to express an experience or thought. But in general, literature is usually divided into two important parts, are prose which is a literary work that is not bound, for example novels, short stories and drama. While poetry, which is a literary work that is bound by certain rules, for example poems.

Linguistics is the study of language, while literature is a part of language which is the application of the meaning in literature language that has an expressive function to show the tone and figure of the speaker or author. Language in literature tries to influence, persuade and eventually change the reader's attitude. Other than that, the most important thing in literary language is the sign and also sound symbolism of words. Various techniques were created to attract attention of the readers. This can be found in some literary works, one of the 
example is novel. The novel has an expressive function because through the novel the author tries to influence, persuade, and even change the attitude of the reader through the tone or figure that is implicitly conveyed.

Meaning is an inseparable part of semantics and always attached to everything what people say. Semantics is the technical term used to refer to the study of meaning (Palmer, 1976). There are two types of meaning mentioned by Keraf; (1) denotative meaning or lexical meaning, that does not contains additional meanings or excessive feelings. In this case the writer only conveys information using denotative words, to give a clear introduction to the facts, (2) connotative or figurative meaning, which contains additional meanings, or certain feelings besides the virtually meaning (Keraf, 2007).

A metaphor is the expression of an understanding one concept in terms of another concept, where there is some similarity or correlation between the two. Metaphor compares two unlike things, but metaphor does not use the words "like" or "as". It is implicit comparison.Metaphors as figurative language contained implicit comparison that compare two things. metaphor actually does not express something directly or explicitly but only give suggestions about the existence of the comparison (Keraf, 1981). Meanwhile, Lakoff and Johnson had a different definition about metaphor. They stated that, metaphor is not just a linguistic expression; it's a delivery in a conceptual system. They said that metaphors infinite to literary works or poetic expressions, but they are broadly than that (Lakoff \& Johnson, 2003).

As a contrary, Richards argued that metaphors should be distinguished as omnipresent principles of language and poetic metaphors. Linguists learned words from their etymology, whereas rhetoricians judged words by the effect metaphors have on the listeners (Richards, 1924). Furthermore, Konrad contrasted linguistic metaphors with aesthetic metaphors. Linguistic metaphors tend to be objects, while aesthetic metaphors give new impressions to objects (Konrad, 1939), (Wellek \& Warren, 1977).

Regarding literary sentences of metaphors in this novel, Ullmann divided metaphors into four types based on their referent categories; (1) Anthropormic metaphor, where it defines the word relation that should be specifically used for human features, but given to inanimate objects. This type of metaphor using parts of the human body or everything related to, as a comparison, (2) Animal Metaphor, which relates to the whole animal, both the behavior and parts of animal body also life around it, (3) Abstract to concrete metaphor that discusses expressions that have abstract object references, are used to express concrete object references or vice versa, and (4) Synesthetic metaphor that talks about the perception that actually matches one of the five senses, is transferred to the other five senses. Or even matched with other things (Ullmann, 2009).

\section{METHODS}

Qualitative method was applied in this article. This designs focus on data collection, analysis, and writing, but they originate out of disciplines and flow throughout the process of research for example types of problems, ethical issues of importance (Creswell, 2014). The data was taken from $A$ Walk to Remember novel by Nicholas Sparks, published in New York 1999. This novel contained 254 pages presented in 13 chapter).

\section{FINDINGS AND DISCUSSION}

There are some types of metaphors according to the experts and their respective opinions. Based on the data about types of metaphors, there are four types of metaphor acording to Ullmann (2009). Here are the data of animal metaphors found in the novel. 
Table 1. Animal Metaphors

\begin{tabular}{|c|c|c|c|}
\hline No. & Pages & Marker & Literary sentences \\
\hline 1. & 19 & fly & $\begin{array}{l}\text {... Sort of followed it up with his own } \\
\text { version, complete with old man } \\
\text { Scrooge becoming a preacher and all, } \\
\text { heading off to Jerusalem to find the } \\
\text { place where Jesus once taught the } \\
\text { scribes. It didn't fly too well. }\end{array}$ \\
\hline 2. & 21 & fishy skin & $\begin{array}{l}\text { And then, just as suddenly, he'd start } \\
\text { to go pale again, back to that fishy } \\
\text { skin. }\end{array}$ \\
\hline 3. & 70 & roast me & $\begin{array}{l}\text { "No way. Absolutely not. My friends } \\
\text { would roast me alive". }\end{array}$ \\
\hline 4. & 138 & $+\infty$ & $\begin{array}{l}\text {...and we rehearsed in the classroom, } \\
\text { because the Play-house wouldn't } \\
\text { open their doors for us until we'd got } \\
\text { all the "little bugs" out of our } \\
\text { performance. }\end{array}$ \\
\hline 5. & 143 & $m \rho$ & $\begin{array}{l}\text { Even though I knew I was doing the } \\
\text { "right thing," my friends didn't } \\
\text { understand it at all, and they'd been } \\
\text { riding me since they'd found out. }\end{array}$ \\
\hline 6. & 151 & pouncing & "Oh, we are," Eric said, pouncing. \\
\hline 7. & 266 & $\begin{array}{l}\text { the little butterflies } \\
\text { already starting }\end{array}$ & $\begin{array}{l}\text { I could feel the little butterflies } \\
\text { already starting to form in my } \\
\text { stomach when Hegbert opened the } \\
\text { door. }\end{array}$ \\
\hline 8. & 351 & gon & $\begin{array}{l}\text { But the disease weakened the rest of } \\
\text { her body as well, preying on her } \\
\text { muscles. }\end{array}$ \\
\hline
\end{tabular}

Based on the data presented in table above, there are 8 literary sentences of animal metaphors found in A Walk To Remember novel. After collecting these data, the writers analyzed the meaning as follows:

(1) ...sort of followed it up with his own version, complete with old man Scrooge becoming a preacher and all, heading off to Jerusalem to find the place where Jesus once taught the scribes. It didn't fly too well (page 19).

Denotative meaning: The denotative meaning in this sentence describes Hegbert who struggled to write his Christmas play and it did not fly too well. While the word fly has the meaning of moving in the air, and it certainly happened because of the help of wings.

Connotative meaning : In this sentence refers to the previous sentence. Meaning of the metaphor in this sentence illustrates the Hegbert's effort in writing a beautiful Christmas play, but the result was unsatisfied because it was not as expected.

(2) And then, just as suddenly, he'd start to go pale again, back to that fishy skin (page 21). 
Denotative meaning :The denotative meaning in this sentence describesfishy skin. Fishy skin will causes fishy smell and the fiah looks pale.

Connotative meaning :This sentence means that Hegbert's skin that turns pale when he started getting angry with those bad boys.

(3) "No way. Absolutely not. My friends would roast me alive" (page 70).

Denotative meaning: The denotative meaning in this sentence describes Landon's friends would roast him alive.Roast means make something cook over fire. And Landon is considered an animal that can be roasted.

Connotative meaning : In this sentence Landon is considered an animal that can be roasted by his friends if he is dating with Jamie. If Landon roasted by his friends, it certainly make his burned and even die. This sentence means that he will be embarrassed, be insulted by his friends, and of course it is embarrassing and even painful.

(4) ... and we rehearsed in the classroom, because the Play-house wouldn't open their doors for us until we'd got all the "little bugs" out of our performance (page 138).

Denotative meaning :The denotative meaning in this sentence describesthe little bugs. Little bugs are usually quite disturbing.

Connotative meaning : A little bugs is a metaphor used in this sentence. Means that in this sentence little bugs describe the character of children (children who role in Christmas play), which tends to interfere and can even damage the attributes or property of play. So they are still rehearsing in the class to get rid of their bad habit and not interfere with each other, so they can rehearse in the playhouse without damaging the property in Playhouse.

(5) Even though I knew I was doing the "right thing," my friends didn't understand it at all, and they'd been riding $m e$ since they'd found out (page 143).

Denotative meaning :The denotative meaning in this sentence describes Landon that ridden by his friends. Riding lexically means horse riding and so on. In this case the rider who has the role and has the right in directing the horse.

Connotative meaning : In this sentence Landon is considered a horse and ridden by his friends because he has been involved in the Christmas play. The things means that his friends have the right to do anything about Landon, include insulting him even with words that might be inappropriate, and Landon is forced to accept everything. The reason because he was already involved in the Christmas play, even though he knew what he did was right. His friends consider the Christmas play to be a joke if Landon joins in, considering Jamie will role in a play with him.

(6) "Oh, we are," Eric said, pouncing (page 151).

Denotative meaning : The denotative meaning in this sentence describes Eric's words is a pounching. Erik's wordscompares with what a wild animal does with deadly danger. Poucning means jump to grip or grasp something.

Connotative meaning : This sentence means that Erik's answer to Jamie's question was considered a dangerous answer to Landon and might kill him, because he had agreed to Jamie's words, which Landon clearly avoid.

(7) I could feel the little butterflies already starting to form in my stomach when Hegbert opened the door (page 266). 
Denotative meaning : The denotative meaning in this sentence describesthe little butterflies that is starting on Landon's stomach. These words are used to indicate the movement of butterflies that occur in the stomach, and it certainly causes a strange taste.

Connotative meaning : The word little butterflies is an animal marker in the sentence above. So this sentence means a strange sensation arises in Landon's feelings. Where this sentence means anxiety and nervousness when Hegbert opened the door of the house before Landon could kiss Jamie.

(8) But the disease weakened the rest of her body as well, preying on her muscles (page.351).

Denotative meaning : The denotative meaning in this sentence describes how Jamie's cancer preying on her mucles. Jamie's cancer is considered to be a prey animal. Lexically, preying means to make a target of evil deeds (more refers to a wild animals).

Connotative meaning : In the sentence above means that Jamie's muscles are the target of his cancer. Which means Jamie's cancer will hurt her body, especially to weaken and destroy the muscles.

\section{CONCLUSION}

The author seems to make the reader curious about the meaning contained in novel, and challenged to find it out. Lliterary sentences used were intended to compare concrete and abstract things. So the readers will understand easily the context in the novel, where figurative language often uses something concrete and abstract.

The use of comparisons in this novel is adapted to the life of and way of communication of teenagers at that time. Figure of speech in communication also describes culture connected to the use of animals' behaviors that are attached to human activities.

\section{References}

Creswell, J. W. (2014). Research design: Qualitative, quantitative, and mixed methods approaches (4th ed). SAGE Publications.

Keraf, G. (1981). Eksposisi dan Deskripsi. Nusa Indah.

Keraf, G. (2007). Diksi dan Gaya Bahasa. Gramedia Pustaka Utama.

Klarer, M. (2013). An Introduction to Literary Studies. Routledge.

Konrad, H. (1939). Étude sur la métaphore. J. Vrin.

Lakoff, G., \& Johnson, M. (2003). Metaphors we live by. University of Chicago Press.

Palmer, F. R. (1976). Semantics. Cambridge University Press.

Richards, I. A. (1924). Priciples of Literary Criticism.

Risdianto, F. (2011). Introduction to Literature. Trust Media Publishing.

Tarigan, H. G. (1985). Pengajaran Semantik. Angkasa.

Ullmann, S. (2009). Pengantar Semantk. Pustaka Pelajar.

Wellek, R., \& Warren, A. (1977). Theory of Literature. Harcourt Brace Jovanovich. 